\title{
An Alternative Method for the Simultaneous Determination of Copper and Lead for Quality Control of Sugar Cane Spirit using a Nanotube-Based Sensor
}

\author{
Elisângela de F. L. Tavares, ${ }^{a}$ Leonardo L. Okumura, ${ }^{*, b}$ Maria das Graças Cardoso, ${ }^{a}$ \\ Marcelo F. de Oliveira ${ }^{c}$, Zuy Maria Magriotis ${ }^{a}$ and Adelir A. Saczk*,a \\ aniversidade Federal de Lavras, 37200-000 Lavras-MG, Brazil \\ ${ }^{b}$ Universidade Federal de Viçosa, 36570-000 Viçosa-MG, Brazil \\ 'Departamento de Química, Faculdade de Filosofia Ciências e Letras de Ribeirão Preto, \\ Universidade de São Paulo, 14040-901 Ribeirão Preto, Brazil
}

\begin{abstract}
Um método eletroanalítico foi desenvolvido para determinação simultânea de íons cobre e chumbo em cachaça empregando eletrodo de pasta de carbono modificado com ácido ascórbico e nanotubos de carbono (CPE-AaCNT). A técnica de voltametria de onda quadrada (SWV) com redissolução anódica foi empregada e otimizada com relação aos seguintes parâmetros: frequência $(50 \mathrm{~Hz})$, amplitude $(100 \mathrm{mV})$ e incremento de varredura $(9 \mathrm{mV})$. As curvas analíticas apresentaram intervalo linear de 0,09 a 7,00 $\mathrm{mg} \mathrm{L}^{-1}$ para o chumbo e para o cobre. Os limites de detecção foram de 48,5 e $23,9 \mu \mathrm{g} \mathrm{L}^{-1}$ para o chumbo e o cobre, respectivamente. O método desenvolvido foi aplicado na determinação simultânea de chumbo e cobre em cinco amostras comerciais de cachaça. Os resultados apresentaram-se concordantes com os obtidos por F AAS/GF AAS (espectrometria de absorção atômica com chama/espectrometria de absorção atômica com forno de grafite) e revelaram que CPE-AaCNT podem ser empregados com êxito na quantificação de cobre e chumbo em amostras comerciais de cachaça.
\end{abstract}

The development of an electroanalytical method for simultaneous determination of copper and lead ions in sugar cane spirit (cachaça) using carbon paste electrode modified with ascorbic acid and carbon nanotubes (CPE-AaCNT) is described. Squarewave voltammetry (SWV) with anodic stripping was employed, and this technique was optimized with respect to the following parameters: frequency $(50 \mathrm{~Hz})$, amplitude $(100 \mathrm{mV})$ and scan increment $(9 \mathrm{mV})$. The analytical curves were linear in the range from 0.0900 to $7.00 \mathrm{mg} \mathrm{L}^{-1}$ for lead and copper. The limits of detection were 48.5 and $23.9 \mu \mathrm{g} \mathrm{L}^{-1}$ for lead and copper, respectively. The developed method was applied to the simultaneous determination of copper and lead in five commercial samples of sugar cane spirit. The results were in good agreement with those obtained by F AAS/GF AAS (flame atomic absorption spectrometry/graphite furnace atomic absorption spectrometry) and showed that CPE-AaCNT can be successfully employed in the simultaneous determination of these metals in real sugar cane spirit samples.

Keywords: copper, lead, carbon paste electrode, multi-walled carbon nanotubes, ascorbic acid, squarewave voltammetry, sugar cane spirit

\section{Introduction}

The sugar cane spirit (usually known as cachaça in Brazil) is the third most consumed distilled beverage in the world, and in Brazil, occupies the first place. Its consumption was estimated at 1.2 billion $\mathrm{L}$ per year in 2008. ${ }^{1}$ According to Sebrae, ${ }^{2}$ the Minas Gerais State

*e-mail: adelir@dqi.ufla.br, leo.okumura@ufv.br
(Brazil) is the largest producer of sugar cane spirit, representing $44 \%$ of the national production. Because of the high consumption of this beverage, and also for marketing and safety purposes, toxicological aspects and evaluation of the levels of accidental or incidental additives in sugar cane spirit should be taken into account. Overall, the demand for chemical analysis of beverages worldwide has been increasing in recent years mainly due to the need for improving the quality standards and industrial 
control. Additionally, when it comes to the quality control of sugar cane spirit, it is important to quantify metals for various purposes. The most important aspect is to check the presence of heavy metal species $(\mathrm{Cu}, \mathrm{Pb}, \mathrm{Zn}, \mathrm{Cd}, \mathrm{As}$, $\mathrm{Al}$, etc.) in toxic levels and to attend to the specifications required by both Brazilian and foreign laws.

The Brazilian Ministry of Agriculture, Livestock and Food Supply (MAPA) established many quality criteria for this product (Normative Instruction No. 13, Official Union Diary, Jun/29/2005). Among these important criteria, the ones related to maximum copper and lead concentrations are of major concern since concentrations higher than $5 \mathrm{mg} \mathrm{L}^{-1}$ for copper and $200 \mathrm{mg} \mathrm{L}^{-1}$ for lead are not allowed. ${ }^{3}$

Copper is an essential element in human beings. However, the consumption of large quantities of this metal can be toxic. Excess copper in the human body can lead to diseases such as Wilson, Menkes, MS, Alzheimer, epilepsy, melanoma and rheumatoid arthritis. ${ }^{4-8}$ Excess lead intake also produces harmful effects on the human health since several organ systems are affected and nervous, gastrointestinal, reproductive, skeletal and biochemical activities are impaired. ${ }^{9,10}$

Analysis of copper and lead in the sugar cane spirit is routinely carried out using flame atomic absorption spectrometry (F AAS), ${ }^{11-16}$ inductively coupled plasma mass spectrometry (ICP-MS) ${ }^{17}$ and UV-Vis spectrophotometry. ${ }^{18,19}$ The electroanalytical techniques can be used as an alternative method in analytical chemistry and offer the additional benefit of being compatible with the principles of green chemistry.

Both copper and lead exhibit good redox activities at some electrode surfaces. Over the last decade, more attention has been given to their inherent electrochemical activity on mercury electrodes. ${ }^{20}$ However, the use of mercury-based electrodes is now considered incompatible with environmental objectives. The modification of electrode substrates with carbon nanotubes (CNTs) and several types of nanoparticles has been recently documented to result in low limits of detection, high sensitivity, reduction of overpotentials, resistance to surface fouling and enhanced electrocatalytic properties. ${ }^{21}$ Despite all these advantages, the CPE-AaCNT electrode has not been evaluated in terms of electroanalytical use and electrocatalytic effects. To the best of our knowledge, the anodic stripping voltammetric determination of copper and lead using a CPE-AaCNT electrode has not been reported in the literature yet. So, the aim of the present work was to develop a convenient and sensitive method for the determination of copper and lead based on the unusual, and not fully explored, properties of multi-walled carbon nanotubes (MWCNT) using ascorbic acid (Aa) as a modifier. This modified electrode was employed for analysis of five real commercial sugar cane spirit samples collected in Lavras City, Minas Gerais State, Brazil.

\section{Experimental}

\section{Reagents}

All the reagents and chemicals used in this work were of analytical grade. Aqueous solutions were prepared with water purified by a Milli-Q system. A solution of $1 \mathrm{~mol} \mathrm{~L}^{-1}$ $\mathrm{HCl}$ was prepared as supporting electrolyte for copper and lead determination. $\mathrm{Cu}^{+2}$ and $\mathrm{Pb}^{+2}$ stock solutions were initially prepared at a concentration of $1000 \mathrm{mg} \mathrm{L}^{-1}$ using copper nitrate (>95\% purity, Synth, Brazil) and lead nitrate (> 95\% purity, Vetec, Brazil), which was followed by dissolution in ultra-pure water solution or $50 \%$ ethanol PA (Qhemis, Brazil). The stock solutions containing $\mathrm{Cu}^{+2}$ and $\mathrm{Pb}^{+2}$ standards were used for further dilutions, as necessary. The commercial sugar cane spirit samples were acquired from different local stores in Lavras (Minas Gerais State, Brazil), in a partnership with the laboratory of analysis of spirits LAFQA at Universidade Federal de Lavras (Minas Gerais State, Brazil). Spectroscopic carbon powder from Merck ( $>99 \%$ purity, Germany) was used in the preparation of the modified electrodes. Mineral oil from Aldrich (>99\% purity, USA) was utilized as the binding agent, and ascorbic acid also from Aldrich ( $>95 \%$ purity, USA) was employed as an additional modifier. MWCNT was purchased in research grade from Nanolab, USA, with $>95 \%$ purity, 10-20 nm diameter, 5-20 $\mu \mathrm{m}$ length, as prepared by the chemical vapor deposition (CVD) technique.

\section{Apparatus}

Squarewave voltammetry (SWV) with anodic stripping analysis was performed on an mAutolab type III potentiostat/galvanostat (ECO-Chemie, The Netherlands) coupled to a microcomputer and controlled by a GPES 4.9 software. A one-compartment electrochemical cell containing a platinum wire auxiliary electrode and an $\mathrm{Ag} / \mathrm{AgCl}_{\text {sat }}$ reference electrode was used for all the voltammetric measurements. CPE-AaCNT was employed as the working electrode. The compositions of the paste from chemically modified electrodes were also analyzed by SEM (scanning electron microscopy) to study their morphology and surface area. To obtain the micrographs, the samples were added on aluminum supports (stubs) with a ribbon on a double-sided film of an aluminum foil and observed under a scanning electron microscope Leo Evo $40 \mathrm{XVP}$ using a voltage of $25 \mathrm{kV}$. 


\section{Electrode preparation}

Carbon paste electrodes (CPEs) were prepared by substituting the corresponding amounts of the carbon powder with carbon nanotubes and/or ascorbic acid in order to obtain the desired composition. The carbon powder/modifier mixture was homogenized in a mortar by using a pestle. Subsequently, the mixture was added to the mineral oil, whose percentage was always kept at $15-22 \%$ $(\mathrm{m} / \mathrm{m})$, depending on the electrode. The new mixture was homogenized again, and the resulting carbon pastes were packed in a cylindrical plastic tube (internal diameter of $3.00 \mathrm{~mm}$ ) and connected with a copper wire, which provided the electric contact. Before use, the electrodes had been polished on A4 paper $80 \mathrm{~g} \mathrm{~m}^{-2}$ for complete removal of excess paste from the surface. The following electrode compositions were tested $(\mathrm{m} / \mathrm{m})$ : ( $i$ ) electrode 1 contained $60 \%$ carbon powder, $25 \%$ ascorbic acid and $15 \%$ mineral oil, (ii) electrode 2 contained $50 \%$ carbon powder, $10 \%$ MWCNT, $25 \%$ ascorbic acid and $15 \%$ mineral oil, and (iii) electrode 3 contained $45 \%$ carbon powder, 10\% MWCNT, 23\% ascorbic acid and 22\% mineral oil.

\section{Analytical procedure}

The analytical procedure comprised three steps: (i) $\mathrm{Cu}^{2+}$ and $\mathrm{Pb}^{2+}$ preconcentration at a specific negative potential directly in the sugar cane spirit sample or standard solution containing 50\% ethanol, (ii) squarewave voltammogram registered with anodic stripping, and (iii) surface regeneration of the electrode by an electrochemical procedure. For the simultaneous determination of copper and lead in commercial sugar cane spirit samples, the preconcentration step was performed directly in the sample or standard solution, without any pretreatment or dilution step, using a known amount of these metals in a controlled time interval and at a negative potential for deposition purposes. Metal quantification in these samples was conducted by the standard addition method. All the measurements were accomplished after deoxygenation of the solution with $\mathrm{N}_{2}$ (White Martins, Brazil) for $15 \mathrm{~min}$, followed by application of a small positive nitrogen pressure to the reaction cell during the voltammetric measurement to exclude atmospheric oxygen. All the experiments were carried out at ambient temperature $\left(25^{\circ} \mathrm{C}\right)$. The results obtained by the electroanalytical method were compared with those obtained by F AAS and GF AAS by means of statistical tests ( $t$ - and $F$-tests).

\section{Recovery experiments}

The standard addition method was used for investigation of the developed methodology in terms of accuracy for sugar cane spirit samples and matrix effect. For this purpose, several samples were analyzed, and the squarewave voltammogram signal was recorded. After that, four additions of equal amounts of $\mathrm{Cu}^{2+}$ and $\mathrm{Pb}^{2+}$ were accomplished up to a final metal concentration of $10 \mathrm{mg} \mathrm{L}^{-1}$. Extrapolation of the resulting linear regression plot gave the amount of $\mathrm{Cu}^{2+}$ and $\mathrm{Pb}^{2+}$ that was recovered from the samples. The results were compared with those obtained by GFAAS and F AAS, and ANOVA (analysis of variance) statistics using $t$-test and $F$-values were also performed.

\section{Results and Discussion}

The morphology of the CPE-AaCNT electrode was examined by SEM, and the images of several compositions of the paste are shown in Figure 1. The surface area of the electrode was gradually affected by the addition of ascorbic acid and MWCNTs. Many uniform agglomerates of MWCNTs can be seen (Figure 1d), and their diameters ranged roughfully between 1 and $5 \mathrm{~nm}$, which completely covered the CPE surface. In the final composition, the superficial area of the electrode was considerably increased as compared to that of the graphite powder only (Figure 1a).

Cyclic voltammetry behavior of $\mathrm{Cu}^{2+}$ and $\mathrm{Pb}^{2+}$ at the CPE-AaCNT electrode

For the initial voltammetric studies, it was attempted to use conventional CPEs with epoxy oil as the binding agent. However, swelling and fouling effects were observed when these electrodes were in contact with ethanolic solutions. This probably happened due to the dissolution of the binder, thus, demonstrating that conventional CPEs are inappropriate for the determination of $\mathrm{Cu}^{+2}$ and $\mathrm{Pb}^{+2}$ in sugar cane spirit samples. To overcome this problem, epoxy was replaced with mineral oil to obtain a more rigid and compact electrode, which can be successfully employed for the direct determination of metals in commercial spirit samples.

Figure 2 presents the cyclic voltammogram registered with CPE-AaCNT at $1.16 \mathrm{mmol} \mathrm{L}^{-1}$ copper and $0.36 \mathrm{mmol} \mathrm{L}^{-1}$ lead in the presence of $0.10 \mathrm{~mol} \mathrm{~L}^{-1} \mathrm{HCl}$ solution, by scanning the potential from -0.70 to $+0.20 \mathrm{~V} v s$. $\mathrm{Ag} \mid \mathrm{AgCl}_{\text {sat }}$. The abovementioned voltammogram was simultaneously registered for copper and lead, using a carbon paste electrode with the following composition: carbon powder/mineral oil/ MWCNT/ascorbic acid 55:23:10:22, m/m. In the studied 
(a)

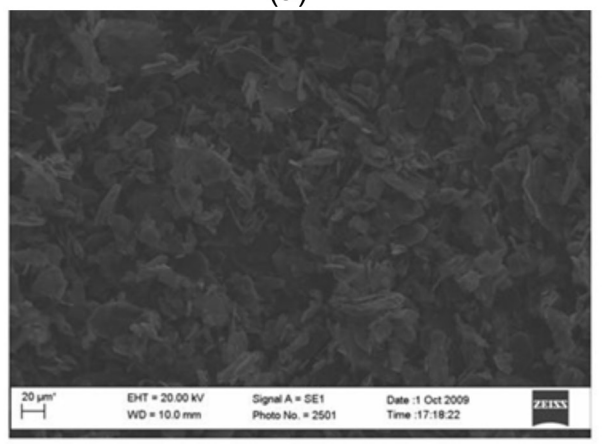

(c)

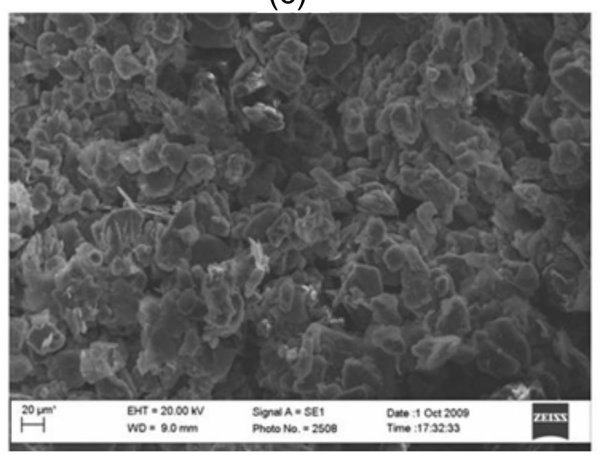

(b)

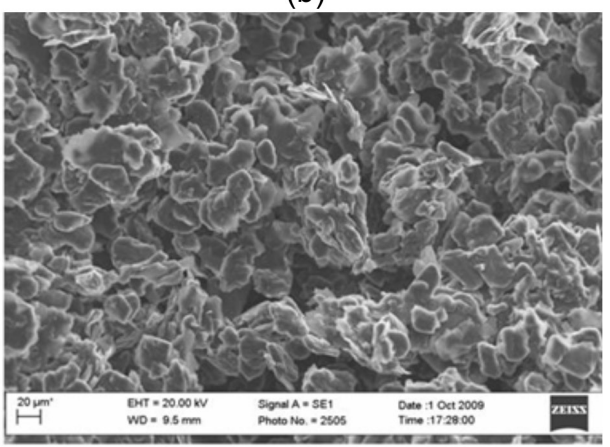

(d)

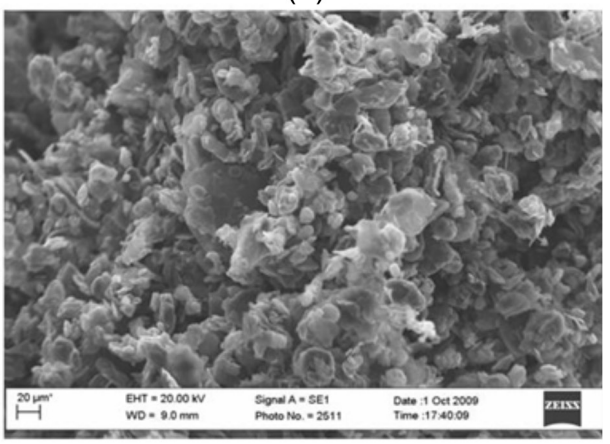

Figure 1. SEM images of the paste electrodes with different compositions: carbon paste containing (a) graphite, (b) graphite + mineral oil, (c) graphite + mineral oil + ascorbic acid and (d) graphite + mineral oil + ascorbic acid + MWCNT.

potential range, there was only one redox reversible couple process for $\mathrm{Cu}^{2+}$ and another one for $\mathrm{Pb}^{2+}$. Moreover, there was a variation in the anodic peak potential $\left(\Delta \mathrm{E}_{\mathrm{p}}\right)$ of $0.37 \mathrm{~V}$ in the redox potentials of the metals, indicating the analytical capability of the method for the determination of these metals in real samples. After checking that it was possible to accomplish the simultaneous determination of copper and lead on the basis of the cyclic voltammogram experiments depicted in Figure 2, the potential initially chosen for reduction of the metals in the preconcentration step of SWV was $-0.60 \mathrm{~V}$ (up to $-1.0 \mathrm{~V}$ ). This is because such potential is more negative than the reduction potentials of copper and lead. In this way, complete reduction of the metals present in the solution on the electrode surface would be ensured for further analysis.

The examination of the voltammetric response of the ions revealed a reduction in the anodic peak current $\left(\mathrm{I}_{\mathrm{pa}}\right)$ $\mathrm{Cu}^{2+}$ in the presence of $\mathrm{Pb}^{+2}$. The presence of this modifier improved $\mathrm{I}_{\mathrm{pa}} \mathrm{Cu}^{2+}$ without interfering $\mathrm{I}_{\mathrm{pa}} \mathrm{Pb}^{2+}$. $\mathrm{Cu}(\mathrm{II})$ ions are chemically reduced by ascorbic acid, forming $\mathrm{Cu}(\mathrm{I})$ ions that, in the subsequence, are electrochemically oxidized, this gives rise to the electrocatalytic cycle shown in Scheme $1 .{ }^{22}$ The use of carbon nanotubes for the synthesis of the electrode material provided greater resistance and greater sensitivity in the simultaneous response of $\mathrm{Cu}^{2+}$ and $\mathrm{Pb}^{2+}$. Any interferents reducing above $-0.8 \mathrm{~V}$ should be effectively excluded from the $\mathrm{Cu}^{2+}$ and $\mathrm{Pb}^{2+}$ measurement.

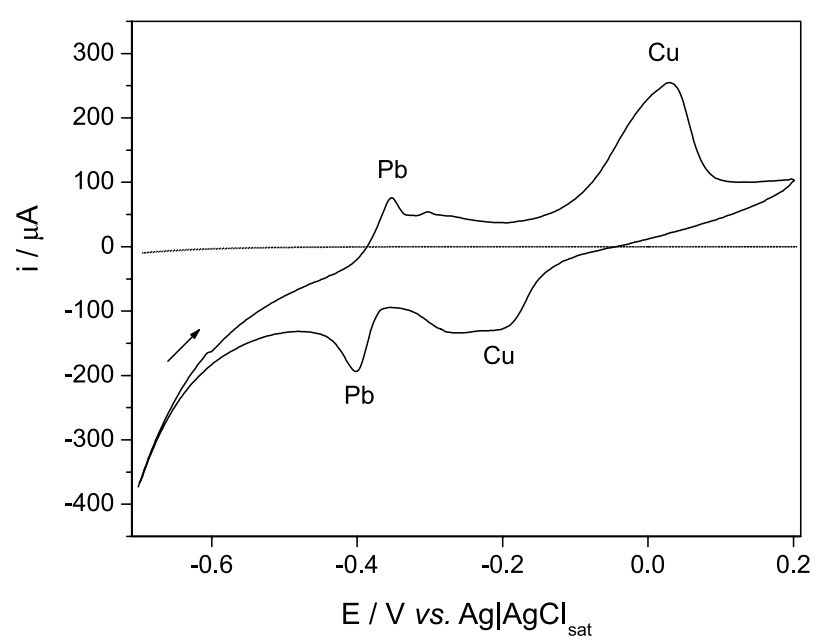

Figure 2. Cyclic voltammogram obtained for the composite electrode containing carbon powder/mineral oil/MWCNT/ascorbic acid 55:23:10:12 $(\mathrm{m} / \mathrm{m})$ in the presence of a solution of $1.16 \mathrm{mmol} \mathrm{L}^{-1}$ $\mathrm{Cu}^{2+}$ and $0.36 \mathrm{mmol} \mathrm{L}^{-1} \mathrm{~Pb}^{2+}$ in $50 \%(\mathrm{v} / \mathrm{v})$ ethanolic supporting electrolyte containing $0.10 \mathrm{~mol} \mathrm{~L}^{-1} \mathrm{HCl}$. Conditions: equilibration time of $5 \mathrm{~s}$ and scan rate of $50 \mathrm{mV} \mathrm{s}^{-1}$.

$$
\begin{aligned}
2 \mathrm{Cu}_{(\mathrm{aq})}^{\mathrm{II}}+\mathrm{AA}_{(\text {surface })} & \rightleftharpoons 2 \mathrm{Cu}_{(\mathrm{aq})}^{\mathrm{I}}+\mathrm{DA}(\text { surface })+2 \mathrm{H}_{(\mathrm{aq})}^{+} \\
2 \mathrm{Cu}_{(\mathrm{aq})}^{\mathrm{I}} & \rightleftharpoons 2 \mathrm{Cu}_{(\mathrm{aq})}^{\mathrm{II}}+\mathrm{e}^{-}
\end{aligned}
$$

Scheme 1. Mechanism of the mediated $\mathrm{Cu}^{+}$oxidation on a carbon paste modified in the presence of L-ascorbic acid. AA = L-ascorbic acid and $\mathrm{DA}=$ dehydroascorbic acid. 
Finally, it is believed that the electrocatalytic properties of MWCNTs in combination with the excellent electronmediating power associated with ascorbic acid make the synergistic CPE-AaCNT sensor system a promising setup for the direct simultaneous detection of $\mathrm{Cu}^{2+}$ and $\mathrm{Pb}^{2+}$ in sugar cane spirit samples, a promising method for quality control purposes.

Influence of preconcentration potential and memory effect

Initially, it was studied whether the simultaneous analysis of copper and lead in spirit by electroanalytical techniques, such as differential pulse, squarewave and linear sweep voltammetry, was feasible. The best results were achieved for squarewave voltammetry with an increment in the peak current intensity of both metals. Thus, the SWV technique was chosen for further analyses.

Figure 3 shows a comparison between two ways of carrying out the preconcentration experiments in SWV, one in an open circuit containing a $\mathrm{Cu}^{2+}$ and $\mathrm{Pb}^{2+}$ solution, and the other in a single step, in which the metals are deposited from their own solution containing $\mathrm{Cu}^{2+}$ and $\mathrm{Pb}^{2+}$ after the anodic stripping step. When the depositing experiment was conducted in the solution containing both $\mathrm{Cu}^{2+}$ and $\mathrm{Pb}^{2+}$ for $30 \mathrm{~s}$, followed by anodic stripping, $\mathrm{i}_{\mathrm{p}}$ significantly increased, and the shape of the voltammograms was much better defined. It is also noteworthy that the concentration necessary for detection of the electrochemical sign was 10 times smaller than that needed for the open circuit deposit step. This means that even at lower $\mathrm{Cu}^{2+}$ and $\mathrm{Pb}^{2+}$ concentrations, the deposit process is efficient. This procedure was thus adopted hereafter.

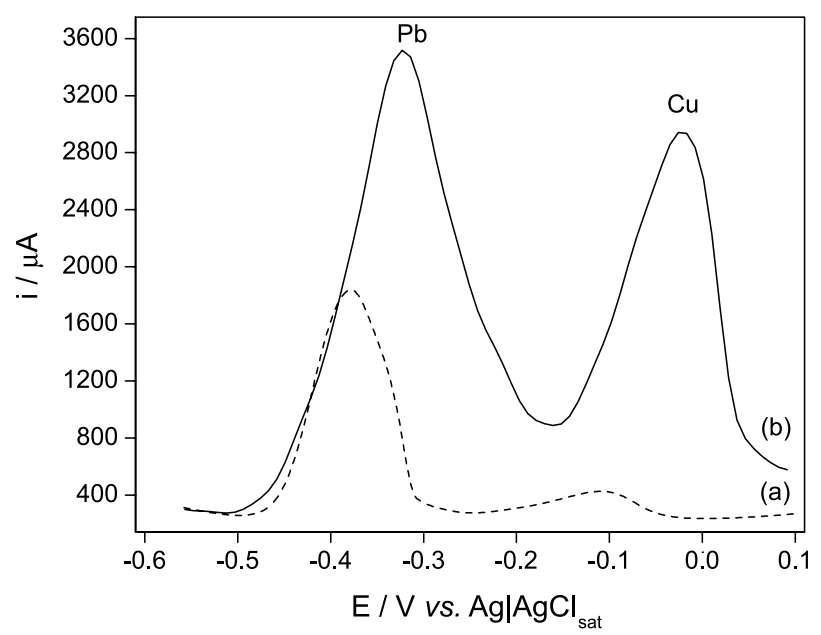

Figure 3. Squarewave voltammograms recorded in $50 \%(\mathrm{v} / \mathrm{v})$ ethanolic supporting electrolyte containing $0.10 \mathrm{~mol} \mathrm{~L}^{-1} \mathrm{HCl}$ after the preconcentration step in open circuit for $300 \mathrm{~s}$ (a) of $200 \mathrm{mg} \mathrm{L}^{-1}$ copper and lead and after the depositing step (b) of $20 \mathrm{mg} \mathrm{L}^{-1}$ of each metal. Conditions: frequency of $60 \mathrm{~Hz}$ and amplitude of $20 \mathrm{mV}$.
Another important analytical parameter investigated was the memory effect in the analysis of metals in standard and spirit solutions containing these metals. This study was performed by using $\mathrm{Cu}^{2+}$ and $\mathrm{Pb}^{2+}$ concentrations of $20.0 \mathrm{mg} \mathrm{L}^{-1}$ in supporting electrolyte $1.0 \mathrm{~mol} \mathrm{~L}^{-1} \mathrm{HCl}$ containing $50 \%$ ethanol (volume), as follows: (i) potential conditioning step ( $-0.80 \mathrm{~V}$ for $30 \mathrm{~s})$, (ii) anodic stripping scan, and (iii) pretreatment potential for the electrode cleaning procedure $(+0.30 \mathrm{~V}$ for $30 \mathrm{~s})$. In general, the electrochemical detection of metals was accompanied by adsorption of these metals or of their oxidation/ reduction products. ${ }^{21}$ For this reason, there was poisoning of the electrode surface and consequent decrease in the electrochemical signal. The complete recovery of the original response was obtained by applying a pretreatment potential of $+0.30 \mathrm{~V}$ for $30 \mathrm{~s}$. The influence of the pretreatment period was also evaluated. This time period was varied from 10 to $60 \mathrm{~s}$, and no difference was seen up to $30 \mathrm{~s}$. Hence, the pretreatment period of $30 \mathrm{~s}$ was chosen for cleaning the electrode surface.

\section{Optimization of SWV conditions}

After evaluation of the optimal conditions for electrode composition, the optimal parameters for the SWV technique that yielded the best results for $\mathrm{Cu}^{2+}$ and $\mathrm{Pb}^{2+}$ stripping analysis were assessed (Table 1). Initially, three parameters were tested: amplitude, potential step (A) and frequency $(f)$ (all of the measurements were carried out using univariate tests).

Table 1. Parameter optimization for the simultaneous determination of copper and lead in $50 \%$ ethanol

\begin{tabular}{lcc}
\hline Parameter & Interval & Best signal \\
\hline Deposit potential / mV & -0.45 to -0.9 & -0.8 \\
Deposit time / s & 30 to 360 & 180 \\
Amplitude / mV & 10 to 100 & 100 \\
Frequency / Hz & 10 to 100 & 50 \\
Step potential / mV & 1 to 10 & 9 \\
\hline
\end{tabular}

\section{Analytical curve}

According to the observed SWV results, it was possible to apply this technique to the quantitative analysis of $\mathrm{Cu}^{2+}$ and $\mathrm{Pb}^{2+}$. The $50 \%$ (v/v) ethanolic solution containing $0.10 \mathrm{~mol} \mathrm{~L}^{-1} \mathrm{HCl}$ was selected as the supporting electrolyte for the quantification of $\mathrm{Cu}^{2+}$ and $\mathrm{Pb}^{2+}$ since it gave the maximum peak current. The peaks at about $-0.40 \mathrm{~V}$ and $-0.10 \mathrm{~V}$ were considered most appropriate for $\mathrm{Pb}^{2+}$ and $\mathrm{Cu}^{2+}$ analysis, respectively. 
Table 2. Experimental results obtained from the linear regression of Figure 6 and analytical figures of merit

\begin{tabular}{lcc}
\hline & $\mathrm{Pb}^{2+}$ & $\mathrm{Cu}^{2+}$ \\
\hline Linear regression & $\mathrm{i}_{\mathrm{p}}(\mathrm{mA})=1.10 \times 10^{-6}+1.06 \times 10^{-4}\left[\mathrm{~Pb}^{2+}\right]\left(\mathrm{mg} \mathrm{L}^{-1}\right)$ & $\mathrm{i}_{\mathrm{p}}(\mu \mathrm{A})=-1.28 \times 10^{-5}+2.61 \times 10^{-4}\left[\mathrm{Cu}^{2+}\right]\left(\mathrm{mg} \mathrm{L}^{-1}\right)$ \\
$\mathrm{r}$ & 0.994 & 0.996 \\
$\mathrm{LOD} /\left(\mu \mathrm{g} \mathrm{L}{ }^{-1}\right)$ & 48.5 & 23.9 \\
$\mathrm{LOQ} /\left(\mu \mathrm{g} \mathrm{L}^{-1}\right)$ & 147 & 72.4 \\
\hline
\end{tabular}

r: correlation coefficient; LOD: limit of detection; LOQ: limit of quantification.

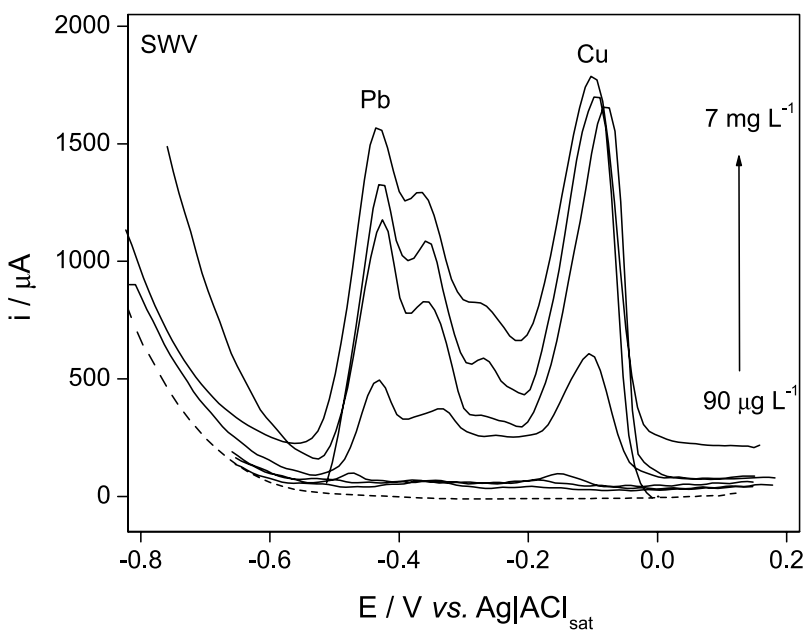

Figure 4. Optimized squarewave voltammetric responses for different $\mathrm{Cu}^{2+}$ and $\mathrm{Pb}^{2+}$ concentrations ranging from $90 \mu \mathrm{g} \mathrm{L}^{-1}$ to $7.0 \mathrm{mg} \mathrm{L}^{-1}$ in $50 \%$ (v/v) ethanolic supporting electrolyte containing $0.10 \mathrm{~mol} \mathrm{~L}^{-1} \mathrm{HCl}$.

Squarewave voltammograms obtained with rising amounts of metals demonstrated that the peak current augmented linearly with increasing concentration (Figure 4). Using the optimum conditions described above, linear analytical curves were constructed for these metals in the range $30.0 \mu \mathrm{g} \mathrm{L}{ }^{-1}$ to $11.5 \mathrm{mg} \mathrm{L}^{-1}\left(4.72 \times 10^{-7}\right.$ to $1.81 \mathrm{~mol} \mathrm{~L}^{-1}$ for $\mathrm{Cu}^{2+}$ and $1.45 \times 10^{-7}$ to $5.55 \times 10^{-5} \mathrm{~mol} \mathrm{~L}{ }^{-1}$ for $\mathrm{Pb}^{2+}$ ), according to Figure 5.

The linear equations for the metals were found according to Table 2. Deviation from linearity was verified for more concentrated solutions (higher than $20.0 \mathrm{mg} \mathrm{L}^{-1}$ ) due to the adsorption or oxidation/reduction of its products on the electrode surface. The limits of detection (LOD) and quantification (LOQ) for $\mathrm{Cu}^{2+}$ and $\mathrm{Pb}^{2+}$ are also given in Table 2. LOD and LOQ were calculated using the following equations:

$\mathrm{LOD}=3 \mathrm{~s} / \mathrm{m}$

$\mathrm{LOQ}=10 \mathrm{~s} / \mathrm{m}$

where $s$ is the standard deviation of the peak currents of the blank (twelve runs), and $\mathrm{m}$ is the slope of each analytical curve. The obtained LOD values are lower than those reported in the literature, ${ }^{13,19,23}$ and these results clearly indicate that the proposed electrochemical method for the
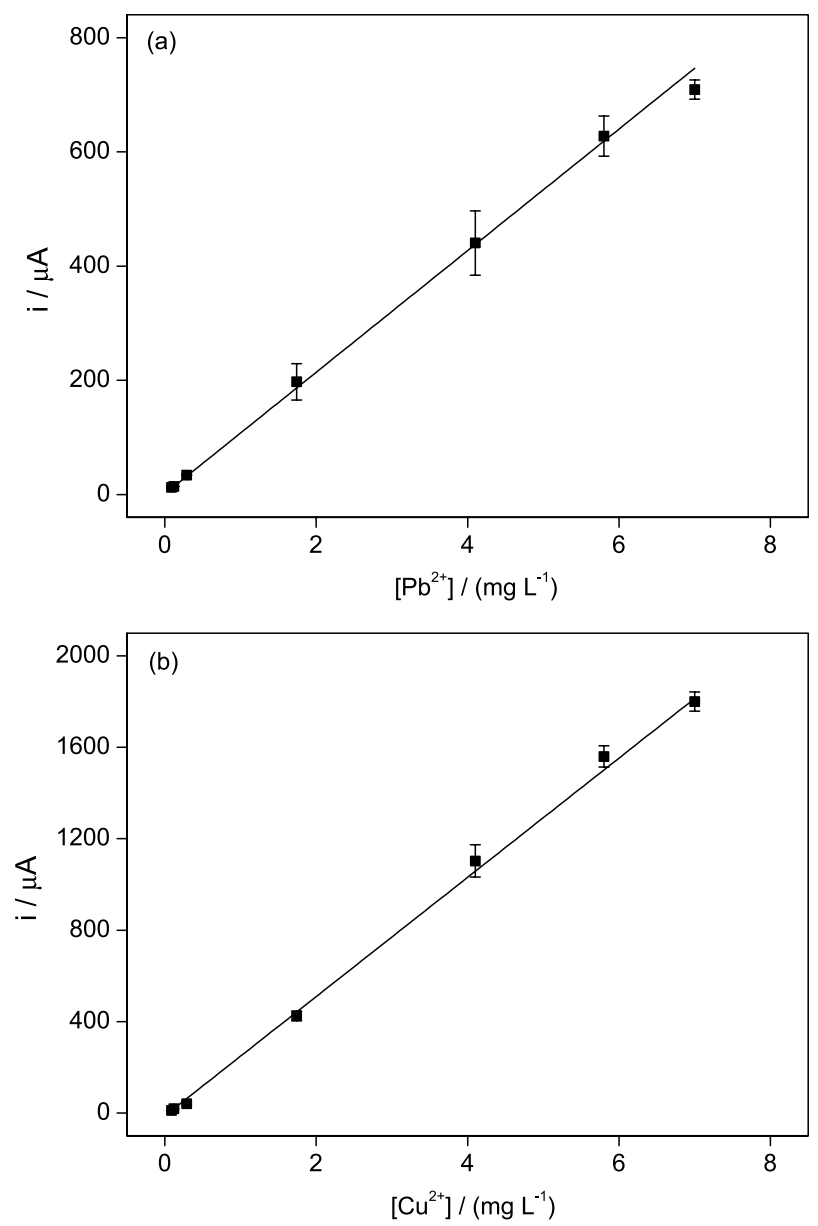

Figure 5. Analytical curves obtained by linear regression for (a) $\mathrm{Pb}^{2+}$ and (b) $\mathrm{Cu}^{2+}$ as previously described in Figure 5. SWV conditions are the same as previously mentioned.

determination of $\mathrm{Cu}^{2+}$ and $\mathrm{Pb}^{2+}$ is reliable, inexpensive and rapid.

Additionally, to study the reproducibility of the electrode preparation procedure, a $1.00 \mathrm{mg} \mathrm{L}^{-1} \mathrm{Cu}^{2+}$ and $\mathrm{Pb}^{2+}$ solution was measured with the same electrode (with a renewed electrode surface for each measurement) for several hours per day. The relative standard deviation (RSD) of the peak current was $0.98 \%$ for $\mathrm{Pb}^{2+}$ and $1.12 \%$ for $\mathrm{Cu}^{2+}$ (number of measurements $=12$ ). Between days, reproducibility was similar to that of within day results, without considerable variation. 


\section{Analysis of commercial sugar cane spirits}

In order to evaluate the applicability of the proposed method in the analysis of commercial sugar cane spirit samples, five real samples were studied. Initially, voltammograms in sample solutions containing the supporting electrolyte and an aliquot of the commercial sample were recorded. Oxidation peaks were observed in all of the five samples, demonstrating the presence of detectable residues of $\mathrm{Cu}^{2+}$ and $\mathrm{Pb}^{2+}$ metals in these matrices, as described in Figure 6.

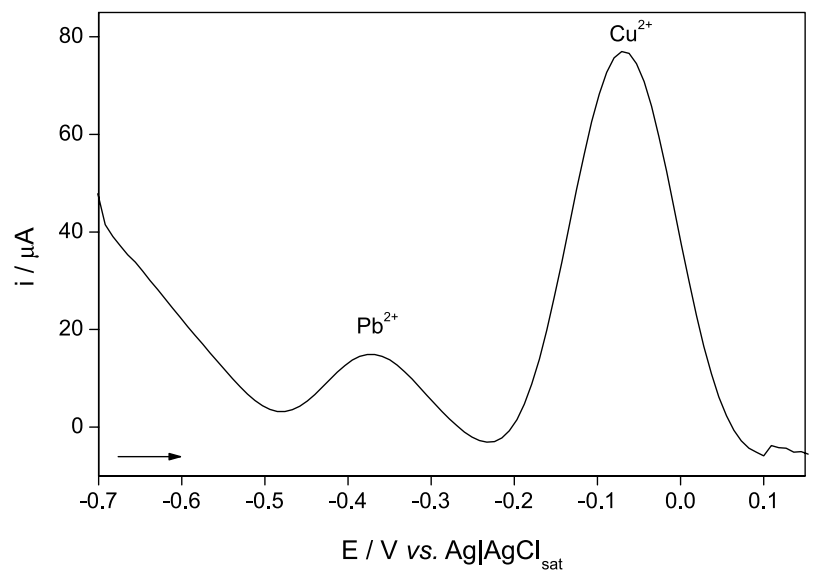

Figure 6. Squarewave voltammogram recorded with the CPE-AaCNT in supporting electrolyte $0.10 \mathrm{~mol} \mathrm{~L}{ }^{-1} \mathrm{HCl}$ for a commercial sugar cane spirit sample. SWV conditions: amplitude of $100 \mathrm{mV}$, deposit potential of $-0.8 \mathrm{~V}$, deposit time of $180 \mathrm{~s}$ and frequency of $50 \mathrm{~Hz}$.

In order to evaluate the application of the proposed SWV methodology and the matrix effect associated with commercial sugar cane spirit samples, the procedures for $\mathrm{Cu}^{2+}$ and $\mathrm{Pb}^{2+}$ analysis followed a standard addition method carried out after the addition of known amounts of $\mathrm{Cu}^{2+}$ and $\mathrm{Pb}^{2+}$ to various samples (4 consecutive additions of $50.0 \mathrm{~mL}$ from a $\mathrm{Cu}^{2+}$ and $\mathrm{Pb}^{2+} 140.0 \mathrm{mg} \mathrm{L}^{-1}$ stock solution), as illustrated in Figure 7. The results obtained using this analytical method were consistent and demonstrated a clear linear relationship in the studied concentration range. The electrochemical response was satisfactory, and a recovery test of $\mathrm{Cu}^{2+}$ and $\mathrm{Pb}^{2+}$ at concentrations ranging from 1.00 to $10.0 \mathrm{mg} \mathrm{L}^{-1}$ was also performed using SWV. The recoveries in different samples lay in the $92.0-110 \%$ range, with lower RSD, indicating that the method can be successfully employed for $\mathrm{Cu}^{2+}$ and $\mathrm{Pb}^{2+}$ determinations in commercial samples. The slope attained for the recovery curve was slightly smaller than the one achieved in the case of the analytical curve, suggesting that the commercial sample presents matrix effects. However, the final recovery percentages showed that this effect does not hinder the application of the method when standard addition method is employed. The decreased sensitivity detected in commercial samples can be attributed to the existence of other metallic ions or organic compounds as contaminants
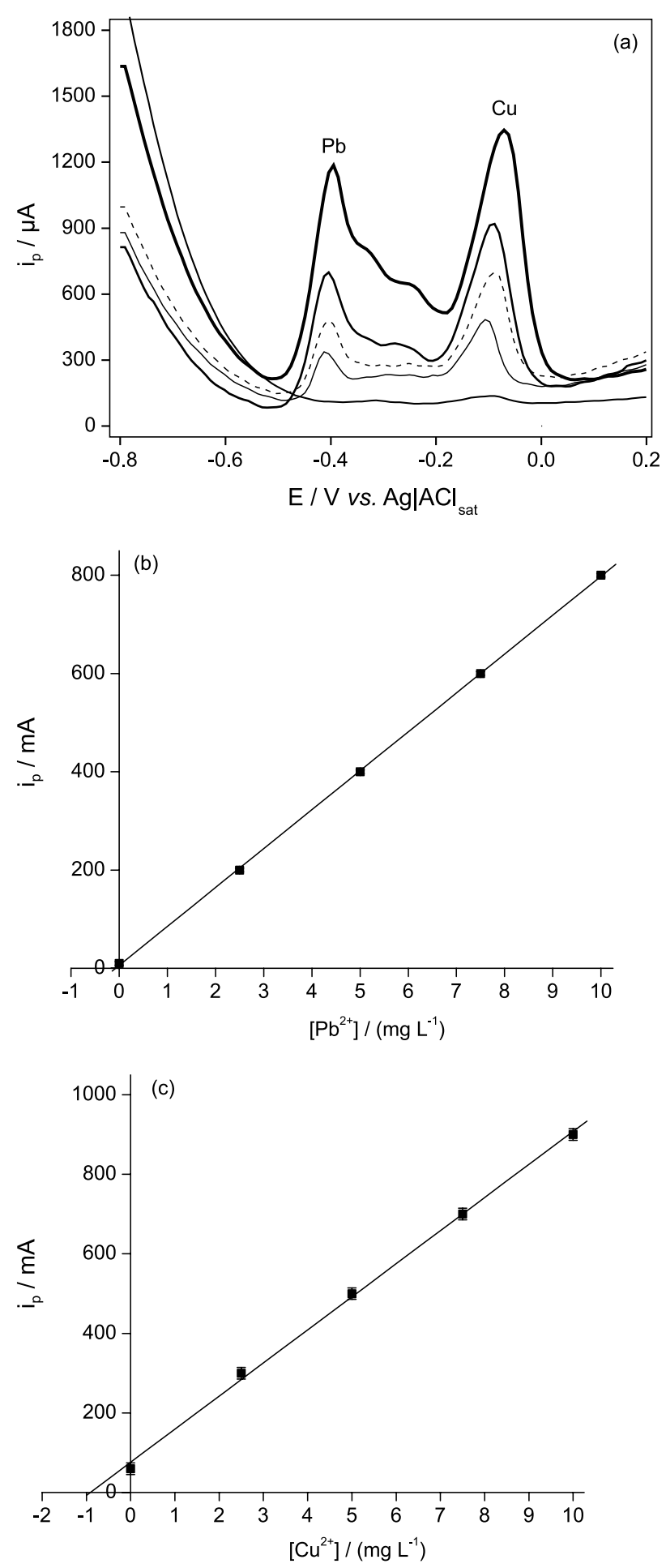

Figure 7. (a) Voltammograms from the standard addition method employed for the simultaneous analysis of $\mathrm{Pb}^{2+}$ and $\mathrm{Cu}^{2+}$ in commercial sugar cane spirit samples. Analytical standard addition method curves are shown for (b) $\mathrm{Pb}^{2+}$ and (c) $\mathrm{Cu}^{2+}$. SWV conditions are the same as in Figure 6. 
Table 3. Determination of copper in sugar cane spirits by the proposed method as compared to GF AAS results and ANOVA statistical results

\begin{tabular}{lcccc}
\hline Commercial sample & $\begin{array}{c}\text { Proposed electrochemical method } \\
\left(\mathrm{mg} \mathrm{L}^{-1}\right)\end{array}$ & F AAS $^{\mathrm{a}} /\left(\mathrm{mg} \mathrm{L}^{-1}\right)$ & $t$-test $^{\mathrm{b}}$ & $F$-test \\
\hline E1 & $0.94 \pm 0.03$ & $0.97 \pm 0.01$ & -1.588 & 7.000 \\
E2 & $0.79 \pm 0.03$ & $0.84 \pm 0.03$ & -1.592 & 1.054 \\
E3 & $1.86 \pm 0.06$ & $1.97 \pm 0.05$ & -2.661 & 5.421 \\
E4 & $0.26 \pm 0.02$ & $0.27 \pm 0.05$ & -0.2182 & 13.00 \\
E5 & $1.63 \pm 0.04$ & $1.60 \pm 0.03$ & 0.0367 & 2.333 \\
\hline
\end{tabular}

${ }^{\mathrm{a}} \mathrm{n}=3 ;{ }^{\mathrm{b}} t_{\text {critical }}=2.896(p=0.05$, with 4 degrees of freedom $) ;{ }^{\mathrm{c}} F_{2 / 2 \text { critical }}=19(p=0.05)$.

Table 4. Determination of lead in sugar cane spirits by the proposed method as compared to GF AAS results and ANOVA statistical results

\begin{tabular}{lccc}
\hline Commercial sample & $\begin{array}{c}\text { Proposed electrochemical method } \\
\left(\mathrm{mg} \mathrm{L}^{-1}\right)\end{array}$ & GF AAS $^{\mathrm{a}}\left(\mathrm{mg} \mathrm{L}^{-1}\right)$ & $t$-tes b \\
\hline E1 & $77 \pm 1$ & $77 \pm 1$ & 0.32 \\
E2 & $\mathrm{ND}$ & $\mathrm{ND}$ & - \\
E3 & $83 \pm 4$ & $80 \pm 3$ & 0.55 \\
E4 & $\mathrm{ND}$ & $\mathrm{ND}$ & - \\
E5 & $\mathrm{ND}$ & $\mathrm{ND}$ & - \\
\hline
\end{tabular}

${ }^{\mathrm{a}} \mathrm{n}=3 ;{ }^{\mathrm{b}} t_{\text {critical }}=2.896(p=0.05$, with 4 degrees of freedom $) ;{ }^{\mathrm{c}} F_{2 / 2 \text { critical }}=19(p=0.05)$; ND: not determined.

in the samples, which are also able to form complexes or react with these metals.

Under the optimum experimental conditions, the effects of potential interferents on the voltammetric response of $5.00 \mathrm{mg} \mathrm{L}^{-1} \mathrm{Cu}^{2+}$ and $\mathrm{Pb}^{2+}$ were also evaluated by means of SWV experiments. The experimental results showed that neither $1.00,5.00$ or $10.0 \mathrm{mg} \mathrm{L}^{-1}$ concentrations of iron and zinc nor a mixture of these metals interfered with the voltammetric signal of $5.00 \mathrm{mg} \mathrm{L}^{-1} \mathrm{Cu}^{2+}$ and $\mathrm{Pb}^{2+}$ for quantitative analysis purposes. $\mathrm{Fe}^{3+}$ and $\mathrm{Zn}^{2+}$ had a significantly opposite effect on the electrochemical signal of copper and lead determination. While the iron contaminant diminished the signal of both metals, zinc intensified then. When both iron and zinc were added to the sample, the lead signal became less intense but the copper signal increased. The stripping signal of copper increased due to the formation of the intermediate $\mathrm{Cu}-\mathrm{Zn}$, which redissolves at potentials closer to the copper stripping peak, with a proportional decrease in the zinc stripping peak. ${ }^{24,25}$ In conclusion, the method of standard addition is mandatory for the quantification of these metals in sugar cane spirits instead of directly using analytical curves.

For comparison purposes, the electrochemical results were confronted with those obtained by F AAS and GFAAS using an ANOVA statistical approach, as described in Table 3 for $\mathrm{Cu}^{2+}$ and Table 4 for $\mathrm{Pb}^{2+}$. These tables evidence that the results obtained by the proposed method agree with those achieved by GF AAS and F AAS for all the analyzed samples. The $t$-values were always smaller than the critical value, indicating that there is no statistical difference between the results from both methods. $F$-values did not exceed the critical value, showing that both methods had similar precisions. Finally, the $\mathrm{Cu}^{2+}$ and $\mathrm{Pb}^{2+}$ contents determined in commercial samples were in good agreement with literature values.

\section{Conclusions}

Our results showed that carbon nanotubes significantly improve the response of the electrode in ethanolic solutions.

The CPE-AaCNT electrode was successfully employed in the development of an electroanalytical method for the simultaneous determination of copper and lead in commercial samples of sugar cane spirit based on the anodic stripping of the metals. The developed method was linear in the range $0.03-8.7 \mathrm{mg} \mathrm{L}^{-1}$ for copper and 0.03-6 $\mathrm{mg} \mathrm{L}^{-1}$ for lead, with LOD equal to 48.5 and $23.9 \mu \mathrm{g} \mathrm{L}^{-1}$, respectively. The presence of interfering ions does not jeopardize the simultaneous determination of copper and lead using CPE-AaCNT when the standard addition method is employed.

The proposed method was applied to five commercial samples of sugar cane spirit for the simultaneous determination of copper and lead. The results for copper were consistent with those obtained by FAAS. Lead cannot be analyzed by F AAS in the experimental conditions used in this work due to the strong matrix effect observed for this spectrometric technique. 
All the samples were in good agreement with the national law requirements established by MAPA, as well as with international requirements for trade purposes.

\section{Acknowledgements}

We thank Universidade Federal de Viçosa (UFV), Universidade Federal de Lavras (UFLA) and Universidade de São Paulo (USP) for their support. The authors also gratefully acknowledge the financial support from Coordenação de Aperfeiçoamento de Pessoal de Nível Superior (CAPES), Conselho Nacional de Desenvolvimento Científico e Tecnológico (CNPq) and Fundação de Amparo à Pesquisa do Estado de Minas Gerais (FAPEMIG) and Fundação de Amparo à Pesquisa do Estado de São Paulo (FAPESP). Finally, we would like to thank PhD Cynthia Maria de Campos Prado Manso for the English revision.

\section{References}

1. Cardoso, M. G.; Produção de Aguardente de Cana, 2a. ed.; Universidade Federal de Lavras: Lavras, MG, Brasil, 2006.

2. Agência de Apoio ao Empreendedor e Pequeno Empresário-MG (Sebrae-MG); Estudo de Viabilidade Econômica, Simulação da Produção de 60 Mil Litros por Safra; Sebrae-MG: Belo Horizonte, MG, Brasil, 2005.

3. http://sistemasweb.agricultura.gov.br/sislegis/action/detalhaAto. do? method=visualizarAtoPortalMapa\& chave $=830709255$ accessed in August, 2012.

4. Janegitz, B. C.; Oliveira, A.; Gomes, M. S.; Sartori, E. R.; Pereira-Filho, E. R.; Fatibello-Filho, O.; Quim. Nova 2010, 33, 458.

5. http://www.agencia.cnptia.embrapa.br/Repositorio/Cachaca_ de_Minas_000fjd717w802wyiv809gkz51uz0mxbc.pdf accessed in August, 2012.

6. Cerpa, W.; Verela-Nallar, L.; Reyner, A. E.; Minniti, A. N.; Inestrosa, N. C.; Mol. Aspects Med. 2005, 26, 405.

7. Waggoner, D. J. Bartnikas, T. B.; Gitlin, J. D.; Neurobiol. Dis. 1999, 6, 221.

8. Sargentelli, V.; Mauro, A. E.; Massabni, A. C.; Quim. Nova 1996, 19, 290.
9. Jurado, J. M.; Martín, M. J.; Pablos, F.; Moreda-Piñeiro, A.; Bermejo-Barrera, P.; Food Chem. 2007, 101, 1296.

10. Kim, M.; Food Addit. Contam. 2004, 21, 154.

11. Pinto, F. G.; Rocha, S. S.; Canuto, M. H., Siebald, H. G. L.; Silva, J. B. B.; Analytica 2005, 17, 48.

12. Oshita, D.; Oliveira, A. P.; Gomes Neto, J. A., Moraes, M.; Eclet. Quím. 2003, 28, 91.

13. Caldas, N. M.; Raposo Jr., J. L.; Gomes Neto, J. A.; Barbosa Jr., F.; Food Chem. 2009, 113, 1266.

14. Labanca, R. A.; Glória, M. B. A.; Gouveia, V. J. P.; Afonso, R. J. C. F.; Quim. Nova 2006, 29, 1110.

15. Peña, Y. P.; Paredes, B.; Rondón, W.; Bueguera, M.; Bueguera, J. L.; Rondón, C.; Carrero, P.; Capote, T.; Talanta 2004, 64, 1351.

16. Catarino, S.; Pinto, D.; Curvelo-Garcia, A. S.; Ciên. Téc. Vitiv. 2003, 18, 65 .

17. Silva, S. R.; Procópio, S. O.; Queiroz, T. F. N.; Dias, L. E.; Rev. Bras. Ciênc. Solo 2004, 28, 189.

18. Azevedo, S. M.; Cardoso, M. G.; Pereira, N. E.; Ribeiro, C. F. S.; Silva, V. F.; Aguiar, F. C.; Ciênc. Agrotec. 2003, 27, 618.

19. Barcelos, L. V. F.; Cardoso, M. G.; Vilela, F. J.; Anjos, J. P.; Quim. Nova 2007, 30, 1009.

20. Barbeira, P. J. S; Stradiotto, N. R.; Fresenius J. Anal. Chem. 1998, 361, 507.

21. Aguí, L.; Yánez-Sedeño, P.; Pingarrón, J. M.; Anal. Chim. Acta 2008, 622, 11.

22. Teixeira, M. F. S.; Ramos, L. A.; Fatibello-Filho, O.; Cavalheiro, E. T. G.; Anal. Bioanal. Chem. 2003, 376, 214.

23. Barbeira, P. J. S.; Mazzo, L. H.; Stradiotto, N. R.; Analyst 1995, 120, 1647.

24. Daniele, S.; Baldo, M. A.; Ugo, P.; Mazzocchin, G. A.; Anal. Chim. Acta 1989, 219, 19.

25. Barbeira, P. J. S.; Stradiotto, N. R.; Talanta 1997, 44, 185.

Submitted: April 12, 2012

Published online: August 15, 2012

FAPESP has sponsored the publication of this article. 